\title{
Dogdom: Nonhuman Others and the Othered Self in Kafka, Beckett and Auster
}

Twentieth-Century Literature, Vol. 62, No. 3 (Duke University Press, September 2016) pp. 271-288

http://tcl.dukejournals.org/content/62/3/271.full

This paper reflects on how Franz Kafka, Samuel Beckett, and, more recently, Paul Auster convey the fundamental 'unknowability' of animal perspectives in their respective prose works 'Investigations of a Dog' (1922), Molloy (1955) and Timbuktu (1999) whilst at the same time conveying the closeness, even liminality, that canines possess. I make the claim that, as with speaking in place of another, speaking for oneself also entails the production of an Other and that these various efforts to read and give voices to dogs underline the rupture of the self-reflective human subject. The failing attempts to read canines result in the successful writing of human ignorance of nonhuman animal worlds, but they also expose the fissure within human autobiography.

Keywords: animal / autobiography / anthropocentrism / modernism / self-reflection / alterity

In an essay on Jacques Derrida's animal philosophy, David Wood writes:

'Anthropocentricism, in some sense, is logically unavoidable, [...]. Any account we come up with of "our" relation to "animals" will be from "our" point of view' (Wood 19-20). The implication is that descriptions and depictions of non-human animals will always be rooted in the human perspective and therefore prioritise the human. Even in the most empathic literary explorations of the lives of animals, an inevitable gravitation to the human self will take place, as all words lead to home. It follows that this unavoidable anthropocentrism includes a kind of life writing, which is to say, 
there is a human autobiographical gesture inscribed within writing on non-human animals, or, to extend on Wood's pronouns, there is a human 'I' implicit in 'our' point of view. The human invariably attends reading and writing endeavours that are seemingly intent on being attentive to other things. Samuel Beckett, a writer renowned for his taciturnity regarding his own work, describes eloquently such reflexivity in a 1949 letter: 'I who hardly ever talk about myself talk about little else' (Beckett, Letters 2 141). Similarly, as writers attempt to represent non-human animals or take imaginative leaps to speak for them, these efforts are bound to be deficient or inadequate, not least owing to the lurking presence of anthropomorphism in the use of human language. In her introduction to the essay anthology Speaking for Animals: Animal Autobiographical Writing, Margo DeMello acknowledges the basic problem confronting writing on animals: 'Because they don't speak our language, and we don't speak theirs, we cannot see, nor can we guess, what's in their mind' (DeMello 5). Such boundaries between human and non-human animals indicate the inability to apprehend and relate animal experiences and their engagement with the world. The indecipherable world of animals reveals the limits of literary creativity and serves to expose the toiling human ventriloquist behind the animal dummy.

The radically secretive, unrepresentable animal, inhabiting what German biologist Jacob von Uexkull labels 'unknown and invisible worlds' is a familiar concept (Uexkull 41). Less familiar is the notion that literature's incongruity with animal worlds at least implies a sense of efficacy when it comes to representing human life. As Karla Armbruster observes: 'The notion that human language cannot capture the fullness of animal existence often carries the unstated assumption that it can capture humans' experience of the world' (Armbruster 26). Franz Kafka, Samuel Beckett and Paul Auster are sceptical of such assumptions and each resort to uncanny 
dehumanised creatures in their writing to subvert the privileging of human language. In Kafka's 1922 short story 'Investigations of a Dog', the dog episodes in Beckett's 1955 novel Molloy and Auster's 1999 novella Timbuktu, the epistemological and expressive poverty in reading and writing animals also occurs within human autobiographical reflections proper. In this essay, I examine experimental prose that challenges humanist assumptions on the reliability of self-reflection to contend that autobiographical deeds are beset by inimical challenges comparable to those encountered in reading and writing animals. In this line of twentieth-century writers, which bear unconscious affinities and declared lineages, the disjunctions that arise between human and non-human animals also occur to an extent between self and writing. Indeed, I argue that, for Kafka, Beckett and Auster, writing the self can involve writing the other; in the same way that writing the other can involve writing the self.

Leigh Gilmore, for example, describes how 'the self becomes oddly multiple just at the time one might think it was most organized and coherent - the moment of telling its own story' (Gilmore 36). Such cases of heteroglossia are commonly attributed to testimonies of traumatic events, in which the distance between the actual experience and the expressed account is magnified. Yet the blind spots and shortcomings of such attestations are also evident in more diffuse traumatic ruptures, such as the modernist tightrope walk between psychological reality and the material, everyday world; the Marxist narrative of the human's severance from the natural world; and, on a more widespread linguistic level, the distance between speaker and the spoken. Beckett exemplifies this last fracture in his 1958 novel The Unnamable through the phrase 'I say I' (Beckett 293). The first pronoun 'I' appears to assert more authority here, as it points out the representational function of the second 
uttered pronoun 'I'. However, Beckett's phrase intimates that the first pronoun is as equally suspect as the second, as a signifier floating away from its signified, which makes the autobiographical 'I' a self-othering expression. Derrida identifies this gap in his seminal lecture for the 1997 'The Autobiographical Animal' conference: "between this relation to the self (this Self, this ipseity) and the I of the "I think," there is, it would seem, an abyss' (Derrida 417). The distance between the real and the representation encourages explorations of others since it already pervades narratives of human self-reflection. Again, Derrida alludes to this note of nonspecific alterity as a basic feature of autobiography: 'The I is anybody at all; [...] Whosoever says "I" or apprehends or poses him or herself as an "I" is a living animal' (Derrida 417). Far from securing itself to the individual, the attempt to articulate the self bypasses the human and non-human animal distinction to betray only a general, anonymous valence. This formulation revises the common admission to the unknowability of animals and contends that human autobiography shares in the profound ignorance.

Dogs in particular evoke a complex range of alienations as liminal animals between the domesticated life of humans and the open wilderness of non-human animals. They are pets granted the title 'man's best friend' that live in close proximity with humans and forge tight fellowships that ineluctably cause them to seep into human consciousness and creativity. In fact, such was the integration of dogs into human thought during the nineteenth and early twentieth century that they figured as annexes of human identity and, by proxy, deserved comparable rights. Susan McHugh identifies this shift in perception: "people not only started to accept the idea they owned dogs as property but, more importantly, envisioned even dogs in the street as representatives or extensions of themselves, if not beings entitled to protection from 
state torture' (McHugh 137). Despite this sentimentality, dogs carry derogatory associative meanings as emblems of menial labour, or 'dog's bodies'; as representatives of the failing, lower echelons of society, or 'the underdogs'; and as visions of abject indigents leading the idiomatic 'dog's life'. The infamous 'No Irish, No Blacks, No Dogs' signs that appeared in London shop windows in the 1950s are a particularly potent example of the dog's integration into human society, but they also illustrate its association with oppressed and ostracised people. The dog retains a negative symbolic value that haunts the image of the loyal and lovable pet so that, in effect, the dog is simultaneously companionable and contemptible.

The dog is a unique animal in human culture on the basis of its pervasive integration into domestic life and deployment as an analogic figure of social segregation. Owing to this curious mixture of inclusion and exclusion, Philip Armstrong proposes that the dog is 'the animal that perhaps more than any other runs to and fro between the human and animal worlds, simultaneously marking and crossing the boundary between them' (Armstrong 17). Given the pervasive presence of canines in the everyday lives of humans, our harmony with dogs appears undoubted and yet the familiarity of the pet can make its difference all the more palpable, and, according to Alice Kuzniar, more painful. Kuzniar writes: 'The melancholic pet owner longs for complete rapport and to know that the dualisms between animal and human are untrue. Yet she is saddened by the inevitable disjointedness and nonsimultaneity between herself and the extimate species, extimacy being that which is exterior to one yet intimately proximate' (Kuzniar 7-8). The dog's relative closeness strengthens the human desire to fully comprehend it but also serves to underline the melancholy of the fundamental separation. It is a dynamic not unfamiliar to humans and emerges especially in autobiographical writing, wherein 
one's own life and human identity can seem oddly detached in the process of reflection and retelling. So, whereas Gertrude Stein raised the possibility of identity being affirmed in dogs, 'I am I because my little dogs knows me', the dog might also give a lesson in living with the simultaneously known and unknown, or, to put it otherwise, the self and the other within the human (Stein 111). For this very reason, Christina Gerhardt locates the suppressed animal in Theodor Adorno's conception of 'the non-identity of identity', whereby 'each entity contains its opposite within itself and is thus constituted, by this tension of identity and non-identity' (Gerhardt 165). If the ancient Greek maxim, 'know thyself' means knowing one's limitations, knowing thyself might also include the impossibility of truly knowing thyself. Ironically, selfknowledge is perhaps the great limitation worthy of acknowledgement, which at once reasserts and refutes the inevitable anthropocentric gravity of animal writing.

\section{'Reflection without end': (De)Anthropomorphism in Kafka's 'Investigations'}

In Franz Kafka's diaries there is over a dozen references to dogs, most of which pertain to incidents that either amuse or disconcert him. Two entries in particular reveal how Kafka aligns himself with the prevalent view of the dog as a lowly, unclean being. In November 1913, Kafka expresses his doubts about writing and all but describes himself as a dog in the process: 'At bottom I am an incapable, ignorant person who, if he had not been compelled - without any effort on his own part and scarcely aware of the compulsion - to go back to school, would be fit only to crouch in a kennel, to leap out when food is offered him, and to leap back when he has swallowed it' (Kafka 237). Kafka's self-disappointment causes him to find affinity with the dog as an image of a miserable, wretched creature, although his education continues to stand out as a redeeming feature. Just over a year later, on 7th February 
1915, Kafka is at a 'complete standstill' with his writing and regards himself as 'execrable' (Kafka 330). The next entry reveals that Kafka's failure to write anything satisfactory is now in an effort to produce a 'dog story' focussing on the very creature to which he related previously when struggling to write. He remarks: 'Wrote a little today and yesterday. Dog story. Just now read the beginning. It is ugly and gives me a headache. In spite of all its truth it is wicked, pedantic, mechanical, a fish barely breathing on the sandbank' (Kafka 330). Kafka finds this dog story incongruous and ill fitting for its purpose, like a fish out of water. His use of the adjectives 'wicked, pedantic, mechanical' implies that his composition is a kind of perversion, as though he has produced a distortion of the natural. It is not certain to what Kafka's 1915 dog story amounted but according to the unforgiving selfcriticism evident in his diaries, it is apparent that Kafka can perceive himself as a dog as a result of the dog tale he cannot write.

Early in 1922, in the lead up to writing 'Investigations of a Dog' in October and November, Kafka suffered a breakdown and experienced a bout of intense selfanalysis. Curiously, his diary entries are less frequent during this time and trail off especially after the summer. In one of the few entries later in the year he records a 'good period', referring presumably to his health, morale or writing, or perhaps all three, and that he had 'made a kind of discovery in the woods' (Kafka 422). Kafka's sustained period of introspection appears to coincide with a decreased interest in using his diaries as a site of life writing and a turn instead to autobiography in his fiction. Kafka spent time with his sister Ottla and walking the landlady's dog, which he mentions in the diaries simply as 'walk with the dog', commenting on 'an innocently attentive animal gaze' (Kafka 422). As with his earlier affinity with dogs and their association with his repeated inability to write, Kafka's proximity with the 
animal during this period merges with his new impetus in autobiographical writing, causing Kafka to invest himself into a dog story. Eric Williams also suggests as much:

'Investigations of a Dog' is the only story he wrote in which all the significant phases of the protagonist's development, from early childhood and pubescence to old age, are fashioned into a life-narrative. Indeed, a short time before beginning this uniquely retrospective Bildungsnovella, Kafka had resolved to remedy the torment that so frequently beset him when "writing denied itself" to him, with a self-reconstruction project that would reverse the tracks of his career: "Hence, [my] plan for autobiographical investigations," he writes. (Williams 100)

The link between Kafka's self-scrutiny and dogs supports autobiographical interpretations of his animal writing. Notwithstanding the temptation to read Kafka in the dog, it is notable that he is traversing the insurmountable gaps of ontological meaning in his story and therefore does not only draw on a kind of ignoble canine alter-ego to uncover his own ignorance and impotence but recognises the predicament as part of canine life also. Kafka embraces the undecipherable, the illegible and the unknowable that apply to human and non-human animal worlds, and allows them to guide his writing methods.

Kafka's short story announces itself as a meditation by a dog for a canine audience. The narrator confesses to be detached from the canine community in the opening lines but nevertheless addresses a canine reader: 'dogs like you and me' (Kafka 281). The report itself contemplates the profound questions of canine 
existence, particularly 'what the canine race nourished itself upon' (Kafka 286) and, without access to genuine scientific objectivity, the narrator surmises that the answers might lie in the community that escapes him. Kafka makes no effort to devise a canine aesthetic as such, preferring instead to couch his dog narrative in rationality and a register that is recognizably human, albeit one that is gradually degraded. The lack of differentiation between species on this front appears to court anthropomorphic and anthropocentric readings. Naama Harel lists several allegorical meanings (the number of which technically refutes the story's allegorical status) including: Jewish identity, homosexual identity, the limit of human consciousness, the attempt to examine the human ability to establish its own existence, and relations between author, as an individual, and society (Harel 50-51). Indeed, this familiar gravitation to the human is an aesthetic snare that yields a convincing analysis suggesting Kafka's dog imitates human anthropocentrism to expose the selfabsorption of all beings. In an essay included in Kafka's Creatures, Margot Norris avers that 'one effect of this story is to turn anthropocentricism inside out by parodying the world of species narcissism which allows humans to perceive creatures purely from their own cultural vantage' (Norris 24). By the narrator's own admission, he is fixated on his own kind: 'all that I cared for was the race of dogs, that and nothing else' (Kafka 289). The narrator virtually erases human intervention from his perception of feeding, training, transporting and hunting, which leads to strange images of these activities with the human absent. In an echo of humanist pride and 'man as the measure of all things', Kafka's narrator claims, 'All knowledge, the totality of all questions and answers, is in the dog' (Kafka 289-90). As a result of this kind of blind self-centeredness, the animal kingdom is disbanded, projecting an implied 'humandom', ‘dogdom', ‘catdom', 'mousedom' and so on, with each world 
revolving around each sovereign species. By showing anthropocentrism back to the reader, or at least 'species-centrism', Kafka is at once censuring and partaking in anthropocentrism. He encourages the human parallel, prompting readers to acknowledge their complicity in this self-centredness, yet Kafka also broadens the scope to suggest that this narcissism is endemic to each species.

Kafka's dog story conveys a universal fixation on homogeneity, which both unites and divides species: unites in the shared insular propensity, divides in the myopia towards others. The far-reaching complication of this gravitation towards the self and alienation from others is a basic lack of self-knowledge, both in the animal's absence of sophisticated self-consciousness and the latency of the human's interminable self-reflection. In Kafka's 'Investigations', the product of this condition is a composite of the autobiographical reflections that Williams identifies and the anthropocentric readings that Harel lists, which together are themselves a projection of the profound estrangements from human and non-human animal neighbours, but also within human autobiography. On one level Kafka's life experiences inject potent personal meanings into the story that in turn illustrate broader socio-political, cultural and religious resonances that can be situated in a geographical and historical context, as several critics have commented. Matthew Powell, for example, claims:

What is clear in "Investigations of a Dog" is that Kafka is not only attempting to portray the obsessive introspection that dominated his life, but also the alienating other(ness) that defined his existence. This need to define the self — and consequently, this need to define other(ness) — was a chronic attempt to search for a reason or a cause for his position as other in European society. (Powell 137) 
This is not a prescriptive meaning but rather one more valid effect of the story, and yet it does little to pacify the troubling suspicion that the dog merely betokens the human, which neglects the meaning of the animal qua animal. An allegorical reading is overly reductive if it continues to prioritise a single ulterior meaning over the surface meaning. With Kafka, it is prudent to approach allegory from the Benjaminian angle, whereby explicit and implicit meanings compete, generating an irresolvable friction and a cloudy sense of meaning. In this way, the integrity of both animal and human stories is maintained and their significances allowed to converse, overlap or made mutually applicable. Rather than only concentrating on marginalised identities, personal social alienation or even the human existential quest, Kafka effects a correspondence between the lack of canine self-knowledge, the lack of human selfknowledge and indeed the impossibility of knowing other species.

Kafka's 'Investigations' cultivates the human-animal common ground through an ambivalent double movement. In an obvious anthropomorphic move, the story performs a humanisation of the dog as it traces the narrator's exploration of his own kind through human logic and language. Contrary to this animal-becoming-human dynamic, Kafka at the same time undermines human logic and language, conveying their inadequacies in the pursuit of knowledge, thus executing a dehumanising tactic, or rather, deposition of the human, in both senses of the word. Kafka's dog tale exposes the fragile properties of the human, thus displacing a secure notion of human identity and thereby testifying to the mysteries of what it really means to be human, or a living creature for that matter. Tellingly, the complexity and scale of the subject matter overwhelms the quasi-scientific, reasoned investigation the narrator carries out. He despairs over the 'superabundance of material', lamenting how truth is 'not only 
beyond the comprehension of any single scholar, but of all our scholars collectively [...] it ever again crumbles away like a neglected ancestral inheritance and must laboriously be rehabilitated anew' (Kafka 287). Confidence in the progress of education and devotion to rigorous academic disciplines are both in vain. Even science, seemingly a root to practical truth in the early 1920s, with confirmations of Einstein's theory of relativity in 1920 and Einstein's Noble Prize for Physics in 1921, adds 'Mere details, mere details, and how uncertain they are' (287). The canine narrator disputes the usefulness of such investigation: 'Science rich in knowledge but poor in practical results' (288). With his simultaneous application of and affront to human methods of gaining knowledge, Kafka anthropomorphises only to deanthropomorphise, if, that is, human identity rests on these privileged properties of self-reflection through language and logic.

Kafka makes it known that when the human conceit is removed, it is not the animal that remains but the bewildering enigma of all living creatures. Walter Benjamin's phrase 'reflection without end' in his essay on Kafka for the tenth anniversary of the author's death helps to describe this empty revelation in perpetually tracing the blank. Benjamin is particularly attentive to the physical nuances in human behaviour that Kafka dislocates from normative human significance. The German critic incisively comments that:

It is possible to read Kafka's animal stories for quite a while without realizing that they are not about human beings at all. When one encounters the name of the creature - monkey, dog, mole - one looks up in fright and realizes that one is already far away from the continent of man. He divests the human gesture 
of its traditional supports and then has a subject for reflection without end. (Benjamin 118).

Kafka dethrones the enlightened human to reveal the recesses, not to illuminate them, but to stare at the darkness of the mystifying human. In doing so, Kafka marks a point of convergence in living creatures' inabilities to identify metaphysical truths about their own kinds and other beings. In this respect, humans and non-human animals are in the same predicament, despite the differences in characteristics and capacities. Indeed, when the dog narrator asks, 'How long will you be able to endure the fact that the world of dogs, as your researches make more and more evident, is pledged to silence and always will be' (Kafka 292), it is clear that it applies to both human and non-human animals, that the same silence engulfs both. Each is an island to the other and to itself.

The elusive human self has certainly not gone unnoticed in Kafka studies, with Peter Stine suggesting that, for Kafka, this self-alienation is a trait shared amongst humans: 'his discovery that language might pursue the self but never reach it led him to envision this failure to reach the goal of self-knowledge as our common fate, and to posit an "indestructible" self permanently hidden from us as his only article of faith" (Stine 58). If this human pursuit of self (and by implication, other) in language is like a dog chasing its tail, it is not a great leap to propose that we can perceive the actual dog as an object, and perhaps subject, of a similar ignorance. The self-reflection in language that fails to locate the human self, also fails to decipher the other, either human or non-human animal. Living creatures are riven from self and other, but, at an acute level, even without language, all are united in their alienation and lack of self or other knowledge, whether through self-reflection or autotelic immersion. For Kafka, 
then, it seems the goal of human language is to evoke the shared silence that sits at the heart of literary anthrozoology and human self-reflection. As with the other writers discussed shortly, Kafka shows awareness of the instability of the distinctions between humans and animals, and the ambiguity of others in his story, besides marking difference, is also, oddly, a point of confluence that allows us to acknowledge and relate to the obscurities of non-human animals. This blindness is not merely an acceptance of human uniqueness and superiority. It is actually a point of relation, in our relative unknowing.

\section{Going To The Dogs: Human-Becoming-Animal in Beckett's Molloy}

If, as Margot Norris asserts, Kafka 'allows the fictional animal to speak itself through or as a deconstructed human' (Norris 19), Beckett's 1953 novel Molloy evokes the animal by way of a similarly ruined version of the human. Whereas Kafka's dog tale must first humanise the dog though in order to then deanthropomorphise the animal, the eponymous Molloy is a human protagonist subject to what might be described as a process of 'animalisation', which does not reverse anthropomorphism as much as level the humanist vision of the human. Beckett's quasi-detective novel of selfdiscovery is divided into two parts, with the first part focussing on the increasingly decrepit Molloy as he sits in his mother's room struggling to relate his recent and failed journey to find his mother. As far as Beckett's limited story arc goes, Molloy's search for his mother is the first indication of a regression to his origin; he is rewinding back to infanthood and the foetal attachment in the womb. Speaking of Beckett's tendency to attenuate and negate, Shane Weller argues that Molloy's mother quest signifies 'a reversal of evolution, an unhumanization rather than a spiritualization' (Weller 99). Whilst the magnetism of the womb has a compelling 
psychoanalytical subtext, Weller shifts the emphasis away from Freudian undertones to accentuate what elsewhere Beckett calls the 'loss of species' (Beckett 82) that sees Molloy dislocated from the normative idea of humanity.

Given that Molloy is one of Beckett's first bold steps in his trilogy of novels also featuring Malone Dies and The Unnamable towards a 'literature of the unword' (Beckett 11), or 'art of failure' (Iser 1), this 'unhumanization' is most distinct in Beckett's deliberately defective aesthetic, which dwells on the inadequacy of expression, the fallibility of narrative, the fragility of knowledge and the creativity of memory, each of which disrupt human capabilities and humanist assumptions. During Molloy's observation of the two rambling strangers A and C, for instance, his desire for clarity and susceptibility to doubt shred through his narrative:

And once again I am I will not say alone, no, that's not like me, but, how shall I say, I don't know, restored to myself, no, I never left myself, free, yes, I don't know what that means but it's the word I mean to use, free to do what, to do nothing, to know, but what, the laws of the mind perhaps, of my mind (Beckett 13)

Despite Molloy pronouncing a newfound freedom to know the laws of his mind, the fragmented irresolute style in which he arrives at this possibility renders the success of such an enterprise highly dubious. The idea that Molloy is capable of anything other than obliviously demonstrating the vacillations of his mind is a joke. Yet, ironically, Molloy is relatively lucid about his deficiencies and manages to recognise his inability to comprehend language: 
Yes, the words I heard, and heard distinctly, having quite a sensitive ear, were heard a first time, then a second, and often even a third, as pure sounds, free of all meaning, and this is probably one of the reasons why conversation was unspeakably painful to me. And the words I uttered myself, and which must nearly always have gone with an effort of the intelligence, were often to me as the buzzing of an insect. And this is perhaps one of the reasons I was so untalkative, I mean this trouble I had in understanding not only what others said to me, but also what I said to them. (Beckett 50)

Molloy is set adrift from the community largely owing to this inability to effectively communicate with others. The capacity to codify the world and share it through signs is unavailable to Molloy. As such, language as a semiotic system dissolves into a purely sensory experience of the sounds, without the associated concepts. This is reinforced by the physical pain Molloy suffers when trying to converse; the abstract values assigned to language have been replaced by the corporal experience of phenomena and sensation. The upshot is that Molloy is distanced from the definition of the human as a rational, speaking animal, despite attempting both of these skills. More pressingly, however, is the fact that Molloy also receives the words he himself utters as peculiar murmuring sounds, comparable to those generated by an insect, an animal of the most alien variety. Unlike Gregor Samsa's creaturely noises in Kafka's Metamorphosis that are nonsense to his immediate family but sound articulate to him, Beckett's Molloy actually perceives his own voice as other. Although the communicative drone and dance of Moran's bees in part two of Molloy lends some vague semblance of meaning to Molloy's murmur, it is evident that his language, a 
defining feature of his humanity, is alien to him. Molloy's communication breakdown not only separates him from other people, then, it separates him from himself.

As Beckett's trilogy of novels unfolds, the reduction of human properties is only exacerbated so that ' $[\mathrm{b}] \mathrm{y}$ the end of the trilogy Beckett hovers over the ruins of modernism, the exhaustion of a certain view of what it is to be human and rational' (Miller 18). Nevertheless, Molloy is undeterred in his attempt at least to relate his own past and make sense of the events of his life. The problem is that as Molloy attempts to scrutinise himself, he inevitably adopts an outside vantage, dividing an already perplexing life into two and then reconstructing it through a doubly mystified lens. In this way, Molloy is practicing what the trilogy as a whole performs: the movement from 'I' to the fallibility of 'I' to the third person implied in every 'I'. Beckett's 1958 novel The Unnamable, the third text in the trilogy, claims to have abandoned 'I' altogether, precisely owing to its duplicity: 'I shall not say I again, ever again, it's too farcical' (Beckett 358). In response to the inability to reconcile the pronoun with the self, Simon Critchley proposes that "the voice is attempting to move from the first person to the third person, from 'I' to 's/he/it' (A Beckettian pun of questionable taste offer itself here, but I will resist)' (Critchley 173). In Beckett's hands, the conviction in 'I' as a complete identification with the whole self perishes and returns to the execrable condition of third person self-reflection, which evokes shades of Kafka in the damning scatological judgment. Beckett is aware that "the very act of trying to perceive oneself separates the self into subject and object' (Barry 123), that 'seeing is an asymmetric action' and 'listening to oneself is almost always already inherent in the act of speaking itself' (124). In the tradition of self-rupture evident in the canine identity of Kafka's 'Investigations', Beckett zooms in on the incipient point of self-expression to trace the extent of the fault lines. 
Over the course of his stumbling story, Molloy is treated as an aberrant social outcast and in turn evokes the lowly dog trope. In an early essay on the presence of dogs in Molloy, Phillip Solomon writes: 'In Molloy, human beings are condemned to lead a dog's life and to die like a dog' (Solomon 91). Beckett himself was in fact fond of dogs, particularly the Kerry Blue terriers his mother May owned at the family home in Foxrock, which were belligerent dogs according to Deidre Bair's biography (Bair 12). In his letters during the 1950s, though, Beckett resorts to more negative conceptions of dogs, such as 'Balzac lying like a dog, abandoned by all, with the smell of gangrene pervading the house' (Beckett, Letters 248). Beckett recognises the precariousness of the dog life, particularly alluding to the rejection from the welfare of the community and the resulting poor physical condition. Furthermore, like Kafka, Beckett also calls upon the trope of dogdom to self-deprecate: 'The dog is duller than ever but its friends know it doesn't mind if they get up and go away' (Beckett, Letters 611). Beckett identifies himself as a dog in this letter to insinuate he is rather unfit for social life. These references continue in his fiction and the decisive dog episode in Beckett's novel occurs when Molloy accidentally runs over and kills Miss Lousse's dog Teddy with his bicycle. The aftermath is worth quoting in full:

instead of grovelling in my turn, invoking my great age and infirmities, I made things worse by trying to run away. I was soon overtaken, by a bloodthirsty mob of both sexes and all ages, for I caught a glimpse of white beards and little almost angel faces, and they were preparing to tear me to pieces when the lady intervened. She said in effect, she told me so later on and I believed her, Leave this poor old man alone. He has killed Teddy, I grant you that, Teddy whom I loved like my own child, but it is not so serious as it seems, for as it 
happens I was taking him to the veterinary surgeon, to have him put out of his misery. For Teddy was old, blind, deaf, crippled with rheumatism and perpetually incontinent, night and day, indoors and out of doors. I would as it were take the place of the dog I had killed, as it for her had taken the place of a child. (Beckett 32-33)

The wise 'white beards' and innocent 'angel faces' readying to rip Molloy to bits anticipate the animalisation of the human evident in Molloy's replacement of the dog. The mob's transformation from a noble and pure idea of civilisation to 'red in tooth and claw' savagery reflects Molloy's own deterioration from integrated citizen to primitive reptilian creature. It is ironic, then, that the animalised Molloy would be quite in keeping with the savage society that bays for his blood and later sees to his exclusion. A second note of irony is that 'old, blind, deaf, crippled with rheumatism and perpetually incontinent' describes Molloy's own state at the end of the story as a confused, needy, decaying figure struggling to conduct his journey properly, in both physical and narrative senses. Molloy therefore replaces Teddy, becomes akin to the dog and exposes the hypocrisy of society in the process.

Although Molloy is a first person narrative from a human perspective, it features the deconstruction of human properties seen in 'Investigations of a Dog', complete with the same unhinging of rhyme and reason. With human ascendancy in ruins, the human can act as a substitute for the animal; Molloy too can be a subjugated pet. The Irish myth of Setanta echoes here, as the man who slayed Culain's guard dog in self-defence and took its place, earning the name Cuchulain, meaning 'Hound of Culain'. To Beckett's mind, the literary inspiration of the myth belongs to the 'antiquarianism' of the Celtic Twilighters that he despised (Knowlson 188-89), but he 
nevertheless retains the fascination with the porous borderlines between human and non-human animals. Indeed, as Weller expresses, with the creaturely Molloy 'Beckett disintegrates the Cartesian human/animal distinction, producing neither a rational animal nor Aristotle's political animal, but rather a human-becoming-animal that counterpoints Kafka's animal-becoming human in his "A Report to an Academy" (1917)' (Weller, Not Rightly Human 215). This Deleuzian 'becoming' unsettles the human-animal distinction to create a 'zone of indiscernibility or undecidability between man and animal' (Deleuze 21). What Weller does not mention, however, is that Teddy the dog was already a replacement for a child, which casts infants, animals and human indigents as interchangeable objects of care. The pet dog in lieu of a child affair is an example of the 'anthropomorphic insolence' that Beckett criticised covertly in his earlier novel Watt (202), but the pet human for pet dog exchange redresses the balance somewhat. This equivalence further compounds the vulnerability of a definite human-animal divide and enters both Molloy and Teddy into a hybrid, creaturely realm. Whether the transformation moves from human to animal or vice versa, the point is that a relation is forged that destabilises the binary.

With the replaceability established, it is possible to view Molloy's inability to master language and narrate his own story as a sign of the autobiographical silence shared by human and non-human animals. Moreover, it is not only that the dogman Molloy is an inadequate storyteller but that the human system of communication wholesale appears deficient. It is revealing, then, that Beckett jotted in his Whoroscope notebook Fritz Mauthner's reflections on the limits of language, 'noting our deluded sense, like a clever dog, that we are free simply because the chain is long' (Ackerley 183). As humans and canines share likenesses in Molloy and are deemed transposable, Beckett promotes a more fluid continuity between beings that supports 
the notion that the natures of self and other are beyond representation and essentially unknowable.

\section{'A man with the heart of a dog': Speaking in lieu in Auster's Timbuktu}

Like Kafka and Beckett, Paul Auster evokes and complicates the 'dog as miserable, wretched creature' trope in his 1999 novella Timbuktu. His emphasis on language in the book and the narrative perspectives it generates repeat the logically inevitable anthropocentric gravitations whilst intimating the mutual blind spots that unite human and non-human animals. Auster's 1987 The New York Trilogy presages his preoccupation with the search for identity and meaning in the world, albeit in exclusively human terms. As with Beckett's loose evocation of crime fiction, Auster takes advantage of the genre's quest for knowledge but repositions the magnifying glass over the searching individual and his engagements with others. Ostensibly, the detective novel thrusts the comprehending, organizing subject to the fore, as Ilana Shiloh notes: 'its interest lies in the human endeavor to apprehend reality' (Shiloh 36). In the first of the tales City of Glass Auster relates novelist-cum-detective Daniel Quinn's surveillance of Peter Stillman and his subsequent unravelling as identity falls foul of multiple invented guises before the target of the case absorbs him. Quinn neglects to assimilate himself into the body of knowledge he so painstakingly accumulates through his figments, including Max Work, Paul Auster, Henry Dark and Peter Stillman Jnr., and he therefore becomes a victim of the 'failure to create a meaningful connection between his inner self and the material world' (Brown 37). In a genre that enacts the workings of the mind, powers of deduction and commitment to scrupulous observation, Auster considers the precarious meaning of the self in a world mediated by language and indistinguishable from fiction, ultimately asking the 
question: 'how do we locate ourselves in the world when language has failed us?' (Brown 45). In Quinn's rootless state, he can be connected to many identities in a way comparable to the polysemy of words. Stillman remarks that Quinn's surname 'flies off in so many directions at once' (Auster 74) to the point where obscure rhymes are used to refer to him. The inclusion of 'djinn' in this list of referents aptly compares Quinn to the magical spirit from Arabian and Islamic mythology that can assume various human and non-human animal forms. Although Auster is firmly fixed on the fragility and mobility of human identity in this crime novel, his reference to the shape shifter in relation to Quinn is an early indication that self-other quandaries can stray into animal ipseity.

The second novel Ghosts follows private eye Blue as he observes his target Black. True to his name, though, Black is impenetrable and deflects his spectator's gaze. The reader discovers that it is 'as though Blue were looking into a mirror, and instead of merely watching another, he finds that he is also watching himself' (Auster 146). According to Shiloh, this means that 'for lack of any external object of perception or locus of significance, [Blue] is bound to direct his look inward' (60). His failed empirical observations result in self-scrutiny, which is also to no avail as his essence evades him. With his individual character non-existent, the tale grows into 'a parable of the human condition: blue and black are everyman, absent to himself and to others, locked in his private consciousness' (67). Clearly, Auster is fascinated by the psychological immersion in the unknowable human other and the apertures in the human self that explorations into alterity uncover, although it is not until Timbuktu that Auster extrapolates to introduce an animal into the equation and thereby move from a human condition to the relationships between living creatures. 
Timbuktu is about a dog called Mr. Bones and his homeless poet owner Willy G. Christmas as they endure the idiomatic 'dog's life', impoverished on the fringes of society. Auster explicitly includes the cliché, writing: 'Dog as metaphor, if you catch my drift, dog as emblem of the downtrodden, and you're no trope, my bod, you're as real as they come' (Auster 57). The irony here is that the metaphor actually applies to Willy himself and, as a result of his vagrancy, the real dog Mr. Bones experiences the grim reality of the figure of speech. McHugh surmises that Mr. bones 'shares the double economic burden of being socially valued as worthless and the immediate dayto-day problems of desperate living' (McHugh 159). Besides this emblematic connection, the man and the dog also intersect in several behavioural respects. Willy is a recovering drug addict prone to psychotic episodes and Mr. Bones remembers an especially dark occasion witnessing Willy 'eating a bowl of his own excrement' (17) and that generally '[h]e stank and drooled' (28). The fact that Willy resembles a dog during his bouts of narcotic-fuelled madness recalls the early nineteenth-century vision of the psychiatric asylum as a menagerie, although Mr. Bones also feels kinship with Willy in more positive ways, perhaps owing to Willy's shared itinerant lifestyle that makes him 'a man with the heart of a dog' (30). Even the phallic valences of Mr. Bones' and Willy's names binds them to libidinal desire, which is all the more convincing given that Mr. Bones next owner is called Dick. The convergence of man and dog in these ways differs from The New York Trilogy in which Auster explored the human other's disruption of the unity of the human self, as Dennis Barone describes: 'When a character loses self-identity it is as if that character has been overfed on the character of an other' (Barone 16). In contrast, in Timbuktu, the repeated, adopted or simply shared behaviours of the dog do not destabilise identity as much as bring hitherto unknown facets of the self to the surface. The 
human potential for animality is underlined later in the novel when Mr. Bones observes a child imitating a wild cat: 'The boy might not have been a real tiger, but that didn't mean he wasn't dangerous. In his own little way, he was more of an animal than Mr. Bones was' (127). This wild substrate is always on the edge of human civilisation, as Mr. Bones' and Willy's border crossings disclose.

In conjunction with the themes of Auster's earlier trilogy, the human-animal resemblances in Timbuktu indicate that there is not always an uncomplicated and indisputable separation of human and no-human animal identities. However, Auster himself claims the novel is less about plot and 'a lot to do with language, which is basically Willy's language and the way Mr. Bones interprets that language' (Auster website). As each attempts to understand the other's language, it is notable that meaning is comprehended but that an unbridgeable gulf remains, which leads to some frustration, especially for Mr. Bones. The narrator says that Mr. Bones' 'grasp of Ingloosh was as good as any other immigrant who had spent seven years on American soil. It was his second language, of course, and quite different from the one his mother had taught him' (Auster 6). This portrait of Mr. Bones' language acquisition likens him to a foreign person, treating the communication barrier as a cultural rather than fundamental difference. Willy repeats this humanising gesture as he decodes the animal's body language: 'It was like learning how to speak a new language, Willy found, like stumbling on to a long-lost tribe of primitive men and having to figure out their impenetrable mores and customs' (37). Willy draws a line of continuity between human and animal, suggesting Mr. Bones' language is a part of his own ancestry. Nevertheless, Mr. Bones dreams of being able to talk properly to his companion, of having the same language, which reasserts the distance between dog and human: 'It feels like talking. It sounds like talking. But that doesn't mean I'm really doing it' 
(181). Despite their close relationship and similarities, then, the man and dog remain separated by their differences and encounter insurmountable barriers to comprehension.

As Auster weaves in the novel's spiritual, metaphysical query referenced in the title 'Timbuktu', humans and animals are re-gathered in contemplating the afterlife in a remote place. As in the dog's dreams, 'in Timbuktu dogs would be able to speak man's language and converse with him as an equal' (50). This spirituality is another point of anthropomorphic creative license regarding the dog, yet their concern with material finitude is undoubtedly mutual. Auster develops a note of parity here between human and dog, not only in the attribution of a conscious spirituality to the animal, which is usually attributed to humans exclusively, but also in their profound ignorance on the subject of death. In the final analysis, both the man and the dog are denied transcendental knowledge and left with the vulnerability of corporal existence in a 'dog eat dog world'. This is literally the case when Mr. Bones is offered food from a Chinese takeaway and 'he couldn't help wondering if he was eating a fellow dog. [...] His appetite would always get the better of him' (107). As with the language barriers that prevent utter comprehension, the pair share a lack of certain knowledge about the metaphysical, and this blindness to kingdom come accentuates the precarious physical survival and dispiriting isolation that human and non-human animals can suffer, especially homeless and stray beings.

Auster highlights basic affinities and distinctions between humans and dogs, and this mixture of familiarity and discreteness presents challenges in devising a narrative mode that can accommodate it. Auster employs a third person narrative perspective and there is a sense of equality in the fact that the third person acts as a witness and filter for both human and canine characters. The narrator insists that 'Mr. 
Bones saw it happen with his own eyes' (3), yet it is apparent that the reader is necessarily receiving a second hand account of the events; we see the human owner through the pet dog through the anthropomorphic narration. The narrator attempts to speak for both man and dog, to articulate lives and worlds that they could not have spoken themselves. Nevertheless, Auster does not always exercise omniscience and he flirts with alienation techniques early in the novel in an attempt to convey $\mathrm{Mr}$. Bones' benighted perspective: 'as surely as the sun was a lamp in the clouds that went off and on every day (3-4). The veracity of the statement is clearly not in keeping with the narrator's knowledge and, at this stage in the novel, Auster employs writing strategies that chase the authenticity of animal autobiography. The narrator is minded to defer authority to Mr. Bones: 'Ignore his opinion if you will, but who else are you prepared to trust? After listening to these stories for the past seven years, had he not earned the right to be called the world's leading authority on the subject?' (15). However, in this appeal to the animal's authority, the narrator exposes his own interfering hand in the tale, as interpreter and translator of the story, and therefore offers only a superficial claim to animal authenticity whilst actually revealing the inadequacy of the narrative strategy. This comes back to the human narrative voice, to that inevitable anthropocentric and autobiographical gesture discussed early in this essay, yet it is as a reflection that admits both human and canine subjects contain mysteries beyond human articulation. Auster's varied, unsteady narrative texture appears to be a metatextual criticism of such writing strategies, pointing out the difficulties that plague attempts to speak for others, whilst betraying how this alterity will remain present when humans and animals are unable to speak for themselves as themselves - when speaking in lieu seems inevitable. 


\section{Conclusion: Dog's Day}

In Kafka's 'Investigations of a Dog', Beckett's Molloy and Auster's Timbuktu, the literary sensitivity not just to animals but living creatures in general is noticeable in the undoing of human language and reliable narrative strategies to reveal the silence that will attest to the unknowable. By drawing connections between humans and animals, in shared narcissism, equivalent statuses, corporal vulnerability, the crisis of representation and problems of apperception, these twentieth-century experimental prose writers move towards a mutual perspective, albeit one that takes a detour through anthropocentrism. The limits of language in Kafka's, Beckett's and Auster's animal stories reveal the blindness to the world of animals that not only reminds us of the human behind it all, but also the human's inability to account for itself, which is a point of kinship with the animal. This openness to obscurity is itself an important nontotalising gesture that is deferential to difference as opposed to imperiously dominating. The supposition that literature could somehow inscribe the animal does an injustice to the complexity of the lives of animals. On the contrary, it is entirely plausible that humans enfold canines into their everyday lives and culture, including our artistic practices, to keep the unknown close and grow familiar with its enigma as an enigma that we also share. As discrete identities reveal such junctions, human and non-human animals appear continuous in substantial ways.

\section{Cited Works}

Ackerley, Chris. "Despised for their Obviousness: Samuel Beckett's Dogs.” Samuel Beckett and Animals. Ed. Mary Bryden. Cambridge: Cambridge University Press, 2013. 177-87.

Armbruster, Karla. "What Do We Want from Talking Animals?” Speaking for Animals: Animal Autobiographical Writing. Ed. Margo DeMello. London: Routledge, 2013. 17-33. 
Armstrong, Philip. What Animals Means in the Fiction of Modernity. London: Routledge, 2008.

Auster, Paul. The New York Trilogy. 1987. London: Faber and Faber, 1988.

_. Timbuktu. London: Faber and Faber, 1999. -. “Q \& A with Paul Auster”. Blue Cricket. 1999. Web. 11 April 2014.

Bair, Deirdre. Samuel Beckett: A Biography. London: Vintage, 1990.

Barone, Dennis, ed. Beyond the Red Notebook - Essays on Paul Auster. Philadelphia: University of Pennsylvania Press, 1995.

Barry, Elizabeth. "One's Own Company: Agency, Identity, and the Middle Voice in the Work of Samuel Beckett." Journal of Modern Literature. Vol. 31, No. 2, 2008. 115-132.

Beckett, Samuel. Disjecta. Ed. Ruby Cohn. London: Calder, 1983.

. The Letters of Samuel Beckett, 1941-1956, Vol. 2. Ed. George Craig, Martha Dow Fehsenfeld, Dan Gunn and Lois More Overbeck. Cambridge: Cambridge University Press, 2011. 2003.

Trilogy - Molloy, Malone Dies, The Unnamable. 1959. London: Calder, Watt. 1953. London: Calder, 1998.

Critchley, Simon. Very Little...Almost Nothing: Death, Philosophy and Literature. Routledge: London, 1997.

Deleuze, Gilles. Francis Bacon - The Logic of Sensation. Trans. Daniel W. Smith. London: Continuum, 2003.

Derrida, Jacques. The Animal That Therefore I Am. Trans. David Wills. New York: Fordham University Press, 2008.

Gerhardt, Christina. "The Ethics of Animals in Adorno and Kafka." New German Critique. No. 97 Adorno and Ethics, 2006. 159-178.

Gilmore, Leigh. The Limits of Autobiography: Trauma and Testimony. Ithaca: Cornell University Press, 2001.

Harel, Naama. "Investigations of a Dog, by a Dog: Between Anthropocentricism and Canine-Centrism.” Speaking for Animals: Animal Autobiographical Writing. Ed. Margo DeMello. London: Routledge, 2013. 49-59.

Iser, Wolfgang. "The Art of Failure: The Stifled Laugh in Beckett's Theatre" Samuel Beckett. Ed. Jennifer Birkett and Kate Ince. London: Pearson, 2000. 201-229. 
Kafka, Franz. Diaries 1910-1923. Ed. Max Brod. New York: Schocken Books, 1976.

. The Complete Short Stories. Ed. Nahum N. Glatzer. London: Vintage Books, 2005.

Knowlson, James. Damned to Fame: The Life of Samuel Beckett. London: Bloomsbury, 1996.

Kuzniar, Alice. Melancholia's Dog: Reflections on Our Animal Kinship. Chicago: University of Chicago, 2006.

Miller, Lawrence. Samuel Beckett: The Expressive Dilemma. Basingstoke: Palgrave, 1992.

Norris, Margot. "Kafka's Hybrids: Thinking Animals and Mirrored Humans." Kafka's Creatures: Animals, Hybrids, and Other Fantastic Beings, Ed. Marc Lucht and Donna Yarri. Plymouth: Lexington Books: 2010.

Powell, Matthew T. "Bestial Representations of Otherness: Kafka's Animal Stories." Journal of Modern Literature. Vol. 32, No. 1. 129-142.

Shiloh, IIana. Paul Auster and the Postmodern Quest: On the Road to Nowhere. New York: Peter Lang, 2002.

Stein, Gertrude. The Geographical History of America, or The Relation of Human Nature to the Human Mind. New York: Vintage, 1973.

Stine, Peter. 'Franz Kafka and Animals', Contemporary Literature, Vol. 22, No. 1 (Winter, 1981). 58-80.

Uexkull, Jacob von. Foray into the Worlds of Animals and Humans: With a Theory of Meaning. Minneapolis: Minnesota University Press, 2010.

Weller, Shane. A Taste for the Negative: Beckett and Nihilism. London: Legenda, 2005.

. "Not Rightly Human: Beckett and Animality." Samuel Beckett Today / Aujourd'hui. Vol. 19, Borderless Beckett / Beckett sans frontières (2008). 211221.

Williams, Eric. "Of Cinema, Food, and Desire: Franz Kafka's "Investigations of a Dog." College Literature. Vol. 34. No. 4 (2007). 92-124.

Wood, David. "Comment ne pas manger - Deconstruction and Humanism." Animal Others: On Ethics, Ontology, and Animal Life. Ed. H. Peter Steeves. Albany: State University of New York Press, 1999. 15-36. 